\title{
Analisis Air Baku Prioritas Skala Kota (Studi Kasus: PDAM Surya Sembada Surabaya)
}

\author{
R. Cipta Anugerah Persada dan Alfan Purnomo \\ Departemen Teknik Lingkungan, Fakultas Teknik Sipil dan Perencanaan, Institut Teknologi Sepuluh Nopember \\ (ITS) Surabaya \\ e-mail: alfanpurnomo@gmail.com
}

\begin{abstract}
Abstrak-Pasokan air baku Kali Surabaya sebesar $20 \mathrm{~m}^{3} /$ detik masih belum mencukupi kebutuhan air rata-rata. Penambahan pasokan air baku dari air mata Umbulan sebesar $1 \mathrm{~m}^{3} /$ detik diperkirakan hanya mencukupi hingga tahun 2017 . Padahal semakin tahun pertumbuhan penduduk semakin naik dan kebutuhan air baik domestik maupun non domestik akan naik pula. Maka dari itu perlunya penambahan sumber air baku untuk memenuhi kebutuhan air tersebut. Padahal jatah debit Kali Surabaya yang diperoleh dari PT Jasa Tirta hanya $10,5 \mathrm{~m}^{3} /$ detik. Analisa penelitian ini dimulai dari mencari tah u kebutuhan air domestik maupun non domestik, kemudian dibandingkan dengan pasokan air dari PDAM Surya Sembada Surabaya. Dari analisa tersebut, akan diketahui apakah pasokan air tersebut sudah memenuhi kebutuhan air Kota Surabaya dalam jangka waktu tertentu. Kemudian bila terjadi defisit, maka akan dicari sumber air-sumber air potensial yang nantinya bisa digunakan untuk sumber air baru. Pemilihan sumber air baku yang berpotensi dipilih berdasar beberapa kriteria yaitu kualitas, kuantitas, kontinuitas, dan keterjangkauan.
\end{abstract}

Kata Kunci-Air Baku, Kualitas, Kuantitas, Kontinuitas, Keterjangkauan, dan PDAM S urya Sembada Surabaya.

\section{PENDAHULUAN}

A IR baku yang digunakan oleh PDAM Surya Sembada Surabaya selama ini berasal dari air sungai. Berdasarkan data dari laporan RISPAM, air Kali Surabaya dapat menyuplai air baku sebesar $20 \mathrm{~m}^{3} /$ detik [7]. Sumber air baku yang digunakan PDAM Surya Sembada selain Kali Surabaya berasal dari mata air Umbulan dan mata air dari wilayah Pandaan. Total debit mata air dapat menyuplai 4 $\mathrm{m}^{3} /$ detik [7]. Di samping itu, pertumbuhan penduduk Kota Surabaya tiap tahunnya mengalami peningkatan. Hal ini mempengaruhi jumlah kebutuhan air minum yang harus dilayani. PDAM Surya Sembada Surabaya memiliki kewajiban untuk memenuhi kebutuhan air minum baik domestik maupun non domestik. Maka dari itu, PDAM Surya Sembada perlu mencari alternatif air baku lain.

Di kota Surabaya sendiri terdapat beberapa air tanah yang berpotensi menjadi sumber air baku bagi PDAM Surabaya. Sumber air baku tersebut ada yang terletak di dalam dan luar kota Surabaya. Beberapa alternatif sumber air baku tersebut antara lain kali Brantas dengan pasokan debit sekitar $4 \mathrm{~m}^{3} /$ detik, sungai Bengawan solo yang juga mampu memasok debit sebesar $4 \mathrm{~m}^{3} /$ detik. Disamping itu terdapat pula Boezem Morokrembangan yang mampu menyuplai sebesar 0,96 1/detik. Air laut sendiri dapat dimanfaatkan sebagai sumber air baku bagi PDAM Surya Sembada Surabaya. Namun perlu teknologi tertentu untuk mengolah air laut tersebut.
Dengan semakin meningkatnya jumlah penduduk kota Surabaya dan makin berkembangnya industri di beberapa kawasan di kota Surabaya maka semakin meningkat pula kebutuhan akan air minum baik sektor domestik maupun non domestik. Maka dari itu PDAM Surya Sembada Surabaya perlu mencari sumber air baku untuk memenuhi air minum dalam jangka panjang.

\section{METODE PENELITIAN}

Pada penelitian ini, dilakukan perhitungan proyeksi kebutuhan air bersih di Kota Surabaya. Kebutuhan air ini terdiri dari kebutuhan air domestik maupun non domestik. Namun sebelumnya ditentukan terlebih dahulu metode yang digunakan untuk proyeksi penduduk. Dalam penelitian ini akan digunakan tiga alternatif metode antara lain yaitu metode aritmatika, metode geometri, dan metode least square [5]. Setelah menentukan metode proyeksi penduduk, dihitung kebutuhan air dengan mengkalikan jumlah penduduk maupun fasilitas umum dengan unit kebutuhan air bersih. Selain itu dihitung pula kehilangan air serta kebutuhan air untuk instalasi pengolahan. Setelah itu didapatkan total kebutuhan air yang harus dipenuhi dan dapat dibandingkan dengan distribusi air PDAM Surya Sembada Surabaya. Setelah itu, jika terjadi defisit air maka perlu pencarian sumber air baku yang dapat digunakan pihak PDAM Surya Sembada Surabaya.

\section{HASIL DAN PEMBAHASAN}

Dalam penelitian ini dibuat grafik dari beberapa metode proyeksi penduduk berdasar perhitungan berikut grafiknya.

\section{A. Metode Aritmatika}

Untuk mengetahui apakah perhitungan tersebut sudah benar atau belum, data tersebut dapat diplot ke dalam grafik yang dapat dilihat pada grafik berikut.

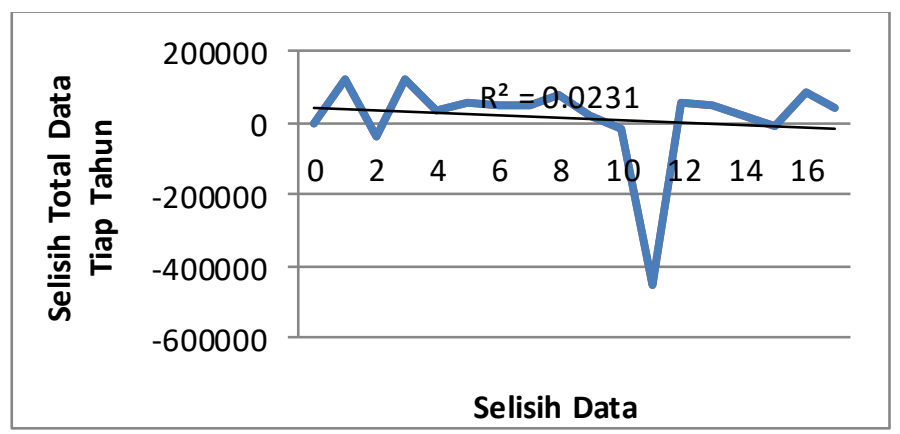

Gambar 1. Grafik Nilai Korelasi Metode Aritmatik 
B. Metode Geometri

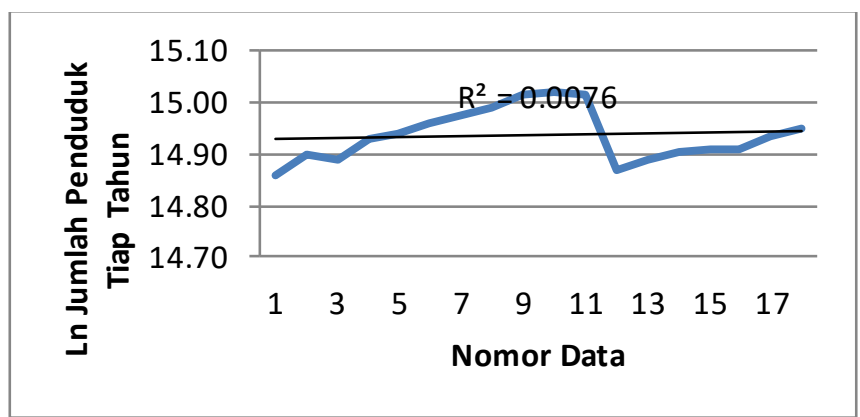

Gambar 2. Grafik Nilai Korelasi Metode Geometrik

\section{Metode Least Square}

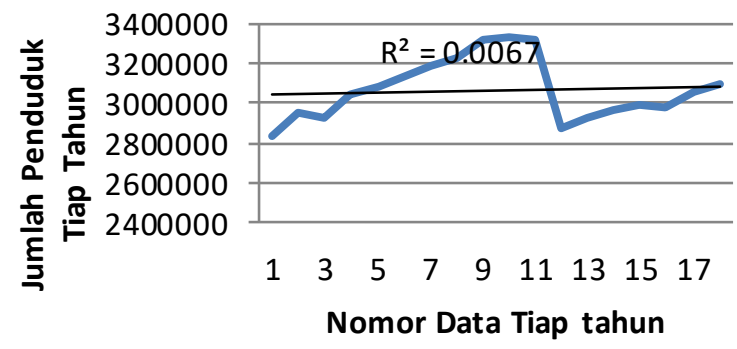

Gambar 3. Grafik Nilai Korelasi Metode Least Square

Dari ketiga metode tersebut, dipilih metode yang memiliki nilai korelasi ( $\mathrm{R}$ ) mendekati angka satu (1). Dari perhitungan di atas metode aritmatika memiliki nilai korelasi ynag paling besar. Namun, metode ini tidak cocok untuk proyeksi penduduk Kota Surabaya yang memiliki kepadatan penduduk yang cukup tinggi. Maka tersisa dua metode, dari kedua metode yaitu geometri dan least square yang memiliki nilai korelasi yang lebih besar yaitu metode geometri. Setelah itu dihitung rasio pertumbuhan penduduk Kota Surabaya sebagai berikut:

Tabel 1

Rasio Pertumbuhan Penduduk

\begin{tabular}{cccc}
\hline \hline Tahun & Penduduk & pertumbuhan & $\mathrm{r}$ \\
2000 & 2835057 & 0 & $0 \%$ \\
\hline 2001 & 2958788 & 123731 & $4.2 \%$ \\
2002 & 2923259 & -35529 & $-1.2 \%$ \\
2003 & 3046063 & 122805 & $4.0 \%$ \\
2004 & 3080820 & 34756 & $1.1 \%$ \\
2005 & 3134261 & 53441 & $1.7 \%$ \\
2006 & 3182891 & 48630 & $1.5 \%$ \\
2007 & 3233761 & 50870 & $1.6 \%$ \\
2008 & 3314441 & 80680 & $2.4 \%$ \\
2009 & 3336838 & 22397 & $0.7 \%$ \\
2010 & 3321125 & -15713 & $-0.5 \%$ \\
2011 & 2868551 & -452574 & $-15.8 \%$ \\
2012 & 2922887 & 54336 & $1.9 \%$ \\
2013 & 2969222 & 46336 & $1.6 \%$ \\
2014 & 2988491 & 19269 & $0.64 \%$ \\
\hline \hline
\end{tabular}

Lanjutan Tabel 4.1

\begin{tabular}{cccc}
\hline \hline 2015 & 2977774 & -10716.5 & $-0.36 \%$ \\
2016 & 3060853 & 83079.19577 & $2.71 \%$ \\
2017 & 3098969 & 38115.99057 & $1.23 \%$ \\
rata-rata & & & $0.41 \%$ \\
\hline \hline
\end{tabular}

Setelah mendapat rasio pertumbuhan penduduknya,maka dihitung proyeksi jumlah penduduknya. Berikut contoh perhitungannya

Spenduduk $2018=\sum$ penduduk $2017\left((1+\% \mathrm{r})^{\mathrm{dn}}\right.$

$$
\begin{aligned}
& =3098969\left((1+0.41 \%)^{1}\right. \\
& =3111771
\end{aligned}
$$

Untuk proyeksi fasilitas umum menggunakan rumus

$$
\frac{\sum P n=\sum F n}{\sum P 0=\sum F 0}
$$

Contoh perhitungannya yaitu

$$
\begin{aligned}
\text { Sindustri } 2018 & =\frac{\left(\text { penduduk 2018x } \sum \text { industri 2017 }\right)}{\sum \text { penduduk } 2017} \\
& =(3111771 \mathrm{x} 409) / 3098969 \\
& =410
\end{aligned}
$$

Jumlah konsumsi dari masing-masing fasilitas umum, didapatkan dari jumlah fasilitas umum dari tahun 2013 hingga 2016 dan rata-rata penggunaan air setiap tahun. Dari

\begin{tabular}{|c|c|c|c|c|}
\hline Keterangan & 2013 & 2014 & 2015 & 2016 \\
\hline Perumahan(L/org.hari) & 230,01 & 232,56 & 233,58 & 237,33 \\
\hline Pemerintah( $\mathrm{m}^{3} /$ unit.hari) & 13,44 & 13,36 & 13,30 & 13,64 \\
\hline Perdagangan(m³/unit.hari) & 2,29 & 2,35 & 2,32 & 2,34 \\
\hline Industri(m³/unit.hari) & 12,18 & 13,05 & 13,86 & 14,19 \\
\hline Sosial Umum(m³/unit.hari) & 3,30 & 3,20 & 3,17 & 3,18 \\
\hline Sosial Khusus(m³/unit .hari) & 14,05 & 14,86 & 14,76 & 14,61 \\
\hline Pelabuhan( $\mathrm{m}^{3} /$ unit.hari) & 222,18 & 247,93 & 226,18 & 216,94 \\
\hline
\end{tabular}
data tersebut didapatkan sebuah rata-rata pemakaian air tiap tahun yang digunakan sebagai unit konsumsi dari masingmasing fasilitas umum. Hasil perhitungan dapat dilihat pada Tabel 2

Tabel 2

Rata-rata Penggunaan Air

Untuk mendapatkan rata-rata penggunaan air dari tiap fasilitas umum, diperlukan perhitungan dari data yang didapat dari PDAM Surya Sembada Surabaya. Data yang didapat dirata-rata dari total penggunaan selama setahun dibagi jumlah pelanggan. Berikut contoh perhitungannya

Penggunaan air industri tahun 2013

Total penggunaan air tahun $2013=1738569 \mathrm{~m}^{3} /$ Tahun

Pelanggan industri tahun $2013=391$

Rata-rata penggunaan air $\quad=1738569 / 391$

$=12,18 \mathrm{~m}^{3} /$ unit/hari

\section{Menghitung Kebutuhan Air}

Setelah itu dihitung kebutuhan air baik dari domestik maupun yang non domestik. Berikut contoh perhitungannya: Sambungan Rumah

Prosentase pelayanan $\quad=100 \%$

Penduduk terlayani $2018=3111771$ orang

Penduduk per $\mathrm{s}$ ambungan $=4$ orang 


$\begin{array}{ll}\text { Jumlah sambungan } & =3111771 / 4 \\ & =777943 \\ \text { Unit konsumsi } & =242 \mathrm{U} \text { orang.hari } \\ \text { Pemakaian rata-rata } & =(3111771 \times 242) / 86400 \\ & =8716 \mathrm{~L} \text { detik }\end{array}$

Non domestik

Pemerintahan

Jumlah 2018

Unit Konsumsi

Pemakaian rata-rata

$=1253$

$=14 \mathrm{~m}^{3} /$ unit.hari

$=(1253 \times 14 \times 1000) 86400$

$=198 \mathrm{~L} / \operatorname{detik} . . . . . . . . . .(\mathrm{a})$

Perdagangan

Jumlah 2018

Unit Konsumsi

Pemakaian rata-rata

$=38003$

$=2 \mathrm{~m}^{3} /$ unit.hari

$=(380003 \times 2 \times 1000) 86400$

$=1029 \mathrm{~L} / \mathrm{detik}$

Industri

Jumlah 2018

Unit Konsumsi

$=410$

$=14 \mathrm{~m}^{3} /$ unit.hari

$=(410 \times 14 \times 1000) 86400$

$=67 \mathrm{~L} / \mathrm{detik}$

Sosial Umum

Jumlah 2018

Unit Konsumsi

$=3834$

$=3 \mathrm{~m}^{3} /$ unit.hari

$=(3834 \times 314 \times 1000) 86400$

$=141 \mathrm{~L} / \mathrm{detik}$

Sosial Khusus

Jumlah 2018

Unit Konsumsi

$=2180$

$=15 \mathrm{~m}^{3} /$ unit.hari

$=(2180 \times 15 \times 1000) 86400$

$=368 \mathrm{~L} / \mathrm{detik}$

Pelabuhan

Jumlah 2018

Unit Konsumsi

$=6$

Pemakaian rata-rata

$=217 \mathrm{~m}^{3} /$ unit.hari

$=(217 \times 6 \times 1000) 86400$

$=15 \mathrm{~L} / \mathrm{detik}$

Q non domestik

$=(\mathrm{a}+\mathrm{b}+\mathrm{c}+\mathrm{d}+\mathrm{e}+\mathrm{f})$

$=1820 \mathrm{~L} / \mathrm{detik}$

Q total

$=$ Qdomestik+Qnon domestik

$=8716 \mathrm{~L} / \mathrm{detik}+1820 \mathrm{~L} / \mathrm{detik}$

$=10535 \mathrm{~L}$ detik

Dari perhitungan penelitian ini diketahui bahwa pada tahun 2018 diperkirakan akan terjadi kekurangan sumber air. Hal ini didapatkan setelah debit rata-rata ditambahkan dengan kebutuhan instalasi pengolahan air. Pada tahun 2018 akan mengalami defisit sebesar $118 \mathrm{~L} /$ detik. Kemudian pada tahun 2035 akan mencapai defisit 2317 Ldetik. Dari data tersebut dapat diketahui bahwa PDAM Surya Sembada Surabaya memerlukan sumber air baku lain untuk memenuhi kebutuhan air tersebut.

\section{E. Sumber Air Baku Yang Berpotensi}

Dari perhitungan kebutuhan air yang dibahas pada pembahasan sebelumnya dapat diketahui bahwa kebutuhan air mengalami defisit pada tahun 2018 dengan kekurangan sebesar 118 Liter/detik. Maka dari itu dibutuhkan pencarian sumber air baku untuk mengatasi masalah tersebut.
Pencarian sumber air baku ini memerlukan waktu dan kajian yang lama. Salah satu acuan untuk memilih sumber air baku dapat menggunakan aturan maupun landasan yang telah ditetapkan pemerintah. Beberapa sumber air baku yang dapat digunakan antara lain mata air, air tanah dalam, sumber air permukaan, dan air hujan.

\section{F. MataAir}

Kuantitas dari mata air yang digunakan PDAM Surya Sembada Surabaya yang telah diketahui menurut data dari PU Sumber Daya Air Tahun 2014 sebesar 110 liter/detik dan menurut data RISPAM 2014 direncanakan mata air yang akan dialokasikan yaitu 500 Ldetik. Namun, dari jumlah debit yang ada di mata air diperkirakan hanya mampu memasok PDAM Surya Sembada Surabaya untuk jangka menengah yaitu sekitar sepuluh hingga lima belas tahun. Untuk kualitas, mata air memiliki kualitas yang baik. Sedangkan untuk sistem distribusinya menggunanakan sistem pompa.

\section{G. Air Tanah Dalam}

Menurut RISPAM 2014, akuifer di Kota Surabaya terdiri dari akuifer dengan aliran ruang dan akuifer bercelah kecil. Untuk akuifer dengan aliran ruang memiliki daerah sumur kurang dari $5 \mathrm{~L}$ detik sedangkan akuifer bercelah kecil terletak pada daerah yang memiliki air tanah langka dan memiliki produksi kecil. Disamping itu kondisi saat ini semakin banyak lokasi di Surabaya yang mengalami intrusi air laut. Maka dari itu diberlakukan perizinan bila ingin melakukan pengeboran air tanah dalam. Sejauh ini pemanfaatannya hanya untuk rumah tangga, industri, dan lain-lain namun tidak memungkinkan untuk sumber air baku PDAM dikarenakan debit yang kecil dan adanya resiko memperbesarnya intrusi air laut.

\section{H. Sumber Air Permukaan}

Untuk sumber air permukaan, di Surabaya terdapat sungai dan bozem. Sungai yang saat ini digunakan PDAM Surya Sembada Surabaya yaitu Kali Surabaya dengan kemampuan memasok $20 \mathrm{~m}^{3} /$ detik menurut data RISPAM 2014. Sedangkan bozem Morokrembangan mampu menyuplai 0,96 Ldetik, namun kondisi curah hujan kota Surabaya yang tidak menentu menjadikan boezem ini sulit digunakan sebagai sumber air baku. Disamping itu debitnya juga terbatas. Untuk mengetahui kualitas dari Kali Surabaya dapat dilihat pada tabel berikut.

\section{Air Hujan}

Untuk air hujan sendiri di Surabaya, seperti yang sudah dijelaskan pada poin sebelumnya bahwa selama ini air hujan ditampung pada waduk atau boezem. Boezem terbessar sendiri yang ada di Surabaya yaitu Boezem Morokrembangan dengan debit mencapai 0,96 L/detik. Jumlah debit ini tentunya kurang mampu mensuplai kekurangan air yang terjadi. Hasil uji kualitas dari boezem Morokrembangan pada Tabel 3. 
Tabel 3 .

Kualitas Boezem Morokrembangan

\begin{tabular}{|c|c|c|c|c|c|c|c|c|c|c|}
\hline \multirow{2}{*}{$\begin{array}{l}\mathrm{N} \\
\mathrm{O}\end{array}$} & \multirow{2}{*}{$\begin{array}{l}\text { Para } \\
\text { meter }\end{array}$} & \multirow{2}{*}{ Satuan } & \multicolumn{7}{|c|}{ Sampling hari ke } & \multirow{2}{*}{ Metode } \\
\hline & & & 1 & 2 & 3 & 4 & 5 & 6 & 7 & \\
\hline & Fisik & & & & & & & & & $\begin{array}{c}\text { Gravime } \\
\text { tri }\end{array}$ \\
\hline 1 & TSS & $\mathrm{mg} / \mathrm{L}$ & 28 & 20 & 22 & 54 & 34 & 56 & 34 & $\begin{array}{c}\text { Gravime } \\
\text { tri }\end{array}$ \\
\hline \multirow[t]{2}{*}{2} & TSS & $\mathrm{mg} / \mathrm{L}$ & $\begin{array}{l}95 \\
6\end{array}$ & $\begin{array}{l}95 \\
2\end{array}$ & $\begin{array}{l}78 \\
8\end{array}$ & $\begin{array}{l}73 \\
6\end{array}$ & $\begin{array}{l}84 \\
4\end{array}$ & $\begin{array}{l}89 \\
6\end{array}$ & $\begin{array}{l}90 \\
8\end{array}$ & \\
\hline & $\begin{array}{c}\text { Kimi } \\
\mathrm{a}\end{array}$ & & & & & & & & & $\begin{array}{c}\text { Iodomet } \\
\text { ri }\end{array}$ \\
\hline 1 & COD & $\begin{array}{c}\mathrm{mg} / \mathrm{L} \\
\mathrm{O} 3\end{array}$ & 80 & 80 & 64 & 76 & 72 & 80 & 86 & Winkler \\
\hline 2 & BOD & $\begin{array}{c}\mathrm{mg} / \mathrm{L} \\
\mathrm{O} 4\end{array}$ & 38 & 38 & 30 & 36 & 34 & 36 & 40 & $\begin{array}{c}\text { Spektrof } \\
\text { ometri }\end{array}$ \\
\hline 3 & Amo & $\mathrm{mg} / \mathrm{N}$ & 75 & 41 & 36 & 48 & 46 & 54 & 58 & Spektrof \\
\hline & nia & $\mathrm{H} 3-\mathrm{N}$ & ,6 & ,4 &, 5 &, 8 & ,9 &, 7 &, 2 & ometri \\
\hline 4 & Phos & $\mathrm{mg} / \mathrm{P}$ & 2. & 1. & 1. & 1. & 1. & 1. & 1. & Spektrof \\
\hline 4 & pat & $\mathrm{O} 4-\mathrm{P}$ & 8 & 7 & 5 & 6 & 5 & 8 & 5 & ometri \\
\hline 5 & $\begin{array}{c}\text { Deter } \\
\text { gen }\end{array}$ & $\begin{array}{c}\mathrm{mg} / \mathrm{L} \\
\mathrm{LAS}\end{array}$ & $\begin{array}{l}4 \\
5\end{array}$ & $\begin{array}{l}5 \\
3\end{array}$ & $\begin{array}{l}4, \\
8\end{array}$ & $\begin{array}{l}4 \\
3\end{array}$ & $\begin{array}{l}3 \\
9\end{array}$ & 5 & $\begin{array}{l}4, \\
6\end{array}$ & $\begin{array}{c}\text { Spektrof } \\
\text { ometri }\end{array}$ \\
\hline
\end{tabular}

Tabel 4

Kualitas Air Laut

\begin{tabular}{lllc}
\hline \hline No & & Parameter & Hasil Uji \\
\hline & 1 & pH & 7.78 \\
& 2 & Suhu & $31 \mathrm{C}$ \\
3 & Kekeruhan & $12 \mathrm{NTU}$ \\
& 4 & TDS & 33960 \\
& 5 & Salinitas & $\mathrm{mg} / \mathrm{L}$ \\
6 & Total Organic Compound (TOC) & $23.90 / 00$ \\
7 & Klorin & $0.387 \mathrm{mg} / \mathrm{L}$ \\
& 8 & Kadmium & $21 \%$ \\
& 9 & Timbal & 0.0014 \\
& & $\mathrm{ppm}$ \\
& &
\end{tabular}

\section{J. Air Laut}

Lokasi kota Surabaya berdekatan dengan pantai yang otomatis berdekatan pula dengan sumber air yang berpotensi yaitu air laut. Untuk kuantitas, air laut memiliki debit yang tak hingga dan diperkirakan mampu memasok dalam jangka panjang yaitu untuk lima belas hingga dua puluh tahun.
Pada Tabel 6 dapat dilihat kualitas air laut dengan sampling lokasi air laut yang berjarak kurang lebih $70 \mathrm{~m}$ dari garis Pantai Kenjeran Lama yang diambil saat kondisi surut dengan kedalaman kurang lebih $50 \mathrm{~cm}$ dari permukaan dengan koordinat $7^{0} 14^{\prime} 15.59$ 'S dan 112)47'47.83"E [1].

Dari beberapa sumber air baku yang berpotensi di atas, ada beberapa sumber air baku yang dapat digunakan untuk sebagai sumber air baku baru. Pemilihan sumber air baku ini didasarkan atas beberapa kriteria yaitu kuantitas, kualitas, kontinuitas, dan keterjangkauan. Berdasar kriteria tersebut sumber air baku yang terpilih yaitu mata air dan air laut.

\section{KESIMPULAN}

Kesimpulan pada penelitian ini adalah sebagaiberikut :

a. Metode yang digunakan untuk proyeksi penduduk yaitu metode geometrik karena mendapat nilai korelasinya paling mendekati 1 . Dari hasil perhitungan proyeksi diketahui bahwa kebutuhan air domestik dan non domestik pada tahun 2035 yaitu 12536 Liter/detik. Disamping itu pasokan air produksi PDAM Surya Sembada Surabaya mengalami defisit sejak tahun 2018 sebesar 118 Ldetik dan pada tahun 2035 defisit kebutuhan air mencapai 2317 Ldetik.

b. Berdasar debit yang mampu dipasok, ada dua alternatif sumber air baku yaitu air laut, dan mata air

\section{UCAPAN TERIMA KASIH}

Penulis RC mengucapkan terimakasih kepada Departemen Teknik Lingkungan dan PDAM Surya Sembada Surabaya yang telah mendukung penelitian ini.

\section{DAFTAR PUSTAKA}

[1] N. L. Hanna, "Kelayakan Teknologi Desalinasi Sebagai Alternatif Penyediaan air Minum Kota Surabaya (Studi Kasus: 50 Liter Per Detik)," Surabaya, 2016. 